\author{
Case Study
}

\title{
AYURVEDIC MANAGEMENT OF RECURRENT PREGNANCY LOSS DUE TO DIMINISHED OVARIAN RESERVE- A CASE REPORT
}

\section{Shahina Mole $\mathbf{S}^{\mathbf{1}}$, Deepa C $\mathbf{R}^{2 *}$ \\ *1 Professor, 2 PG Scholar, Department of Prasoothi Tantra and Stree roga, Govt. Ayurveda College,} Thiruvananthapuram, Kerala, India.

\begin{tabular}{l}
\hline Article info \\
\hline Article History: \\
Received: $30-11-2021$ \\
Revised: $11-12-2021$ \\
Accepted: 20-12-2021 \\
\hline KEYWORDS: \\
Infertility, \\
Vandhyata, \\
Recurrent pregnancy \\
loss, Diminished \\
ovarian reserve.
\end{tabular}

\section{INTRODUCTION}

Infertility is defined as the failure to conceive after one year of regular unprotected coitus [1]. About $80 \%$ of the couple achieves conception within one year of having regular intercourse with adequate frequency. Conception depends on the fertility potential of both the male and female partner. For pregnancy to occur ovulation, ovum transportation by the tube, presence of normal sperms, fertilization and implantation are essential. Among etiology of infertility male factor contribute to $30 \%$, female factor contribute to $40-55 \%$, both male and female factor contribute to $10-20 \%$, and $15 \%$ are comes under unexplained infertility ${ }^{[2]}$.

\begin{tabular}{|l|l|}
\hline \multicolumn{3}{|c|}{ Access this article online } \\
\hline Quick Response Code & \\
\hline https://doi.org/10.47070/ijapr.v9i12.2213 \\
\hline
\end{tabular}

The cause of female infertility include ovarian factors, tubal factors, age related factors, uterine problems, endometriosis etc. Ovulatory disorder is one of the most common reasons of female infertility. The problem of infertility is fairly common nowadays and it has become need of the hour to find out solution which is having less complication and affordable.

According to Ayurveda, infertility refers to the biological inability of a women of reproductive age group to conceive and unable to carry pregnancy to full term. That is failure to achieve a child rather than pregnancy as Garbha srava (abortion) and Mruthavatsa (stillbirth) are also included in the types of infertility ${ }^{[3]}$. Rithu (fertile period), Kshetra (reproductive organs), Ambu (nutritive fluids) Bija (sperm and ovum) are considered as Garbhasambhava samagri (essential factors of conception) ${ }^{[4]}$. In addition healthy psychological status and normal functioning of Vata are essential. Infertility management in Ayurveda focused on the establishment of proper functioning of all these. 
Recurrent pregnancy loss is defined as two or more spontaneous miscarriage before the fetus reach viability. Etiology includes genetic causes, congenital and acquired anatomical abnormalities of reproductive tract, Poly Cystic Ovarian Disease (PCOD), Diminishing Ovarian Reserve (DOR), thyroid dysfunctions, immunological causes, infections etc. Among them Diminishing Ovarian Reserve (DOR) is a complex phenomenon and exact mechanism of development of DOR is unknown. This is an important limiting factor for the success of any treatment modality for infertility. In DOR functional reproductive potential is reduced due to reduction in oocyte quality and quantity. Diminished ovarian reserve is a phenomenon often noted in women in their mild to late thirties, but it may affect younger women as well. There is accelerated decline in follicular pool above 35 years and this phenomenon is accompanied by declining quality due to aging oocyte. Hence younger women with DOR may have better chance at conception, but with high risk of pregnancy loss ${ }^{[5]}$. Ayurveda concept include both Bija roopa artava (quality of ovum) and Dhatu rupa artava (hormonal function) Dushti which leading to recurrent pregnancy loss and it can be taken as Garbhasravi vandhya.

\section{Case Report}

A 24 year old female presented to the OPD of Dept. of PTSR, GAVC TVM with complaint of inability to beget a viable child even after 3 years of unprotected sexual life. The patient attained menarche at the age of 13 years and she had regular cycles. She got married at the age of 22 to man of 32 years. It was a nonconsanguineous marriage. She conceived naturally within one year (Sep 2017). But medical termination

\section{Roga Rogi Pareeksha}

\begin{tabular}{|l|l|}
\hline Dosha & Vata, Pitta, Kapha \\
\hline Dooshya & Rasa, Rakta, Artava, Mamsa, Medas \\
\hline Srotas & Rasam, Rakta, Mamsa, Artava, Medas \\
\hline Deha desa & Garbhasaya \\
\hline Rogi bala & Madhyama \\
\hline Roga bala & Pravara \\
\hline Vyadhi avasta & Purana \\
\hline Anala & Madhyama \\
\hline Satmya & Madhyama \\
\hline Abhyavaharana Sakti & Madhyama \\
\hline Jarana Sakti & Madhyama \\
\hline Prakruti & Kapha pitta \\
\hline Vaya & Madhyama \\
\hline Satwa & Avara \\
\hline
\end{tabular}

Diagnosis: Garbhasravi Vandhya did at $8^{\text {th }}$ week because of absence of fetal cardiac activity. After 6 months (April 2018) she conceived again but was diagnosed as ectopic pregnancy and had spontaneous abortion. Then she consulted an infertility clinic and on detailed evaluation she was diagnosed with Diminished Ovarian Reserve (DOR). They advised Ayurveda treatment and got admitted in our hospital. She underwent one course IP management and conceived in April 2019 but had a spontaneous abortion. After that patient developed severe pain and stiffness over both leg and emotional disturbances. She had admitted here for next course IP management.

On detailed assessment her menstrual cycle was regular with interval of 26 to 30 days. Duration of bleeding was 3 to 4 days with moderate dysmenorrhea on day 1 . She had occasional mucous white discharge per vagina with mild itching especially before the onset of cycles. Obstetrical history shows A3P0. She had no dyspareunia and aware about fertile period. Past history reveals hypothyroidism and she was under Thyronorm $125 \mathrm{mcg}$ for last five years. On general examination the patient was obese with moderate work style, mixed diet with preference to spicy hot food. Psychological status was depressed with sleep disturbances. On per vaginal examination external genitalia were normal without any anatomical defect. No discharge seen externally. Per-speculum examination shows mild cervical erosion and white mucous discharge from vaginal walls. On investigations her AMH was $1.1 \mathrm{ng} / \mathrm{ml}$. USG pelvis shows normal uterus and adnexa. Follicular study shows an AFC count of 3 on right and 2 on left ovary. 
Int. J. Ayur. Pharma Research, 2021;9(12):28-33

\section{Internal Medicines in First Course Treatment}

\begin{tabular}{|l|l|l|}
\hline S. No & Internal medicines & Dose \\
\hline 1. & Sapthasaram kashaya & $90 \mathrm{ml}$ twice daily before food \\
\hline 2. & Maharasnadi kashaya & $90 \mathrm{ml}$ twice daily before food \\
\hline 3. & Phalasarpis & $10 \mathrm{gm}$ bed time \\
\hline
\end{tabular}

Procedure Done in First Course of Treatment

\begin{tabular}{|c|l|l|l|}
\hline Sl. No & \multicolumn{1}{|c|}{ Procedure } & \multicolumn{1}{|c|}{ Medicine } & \multicolumn{1}{|c|}{ Duration } \\
\hline 1. & Udwarthana & Kolakulathadi choorna & 14 days \\
\hline 2. & Yoni kshalana & Triphala kashaya & 7 days \\
\hline 3. & Virechana & Gandharva eranda 20ml & 3 Vegas \\
\hline 4. & Snehapana & Pippalyadi anuvasana taila & $\begin{array}{l}\text { For 7 days }(30 \mathrm{ml}, 60 \mathrm{ml}, 90 \mathrm{ml}, \\
100 \mathrm{ml}, 125 \mathrm{ml}, 150 \mathrm{ml}, 175 \mathrm{ml})\end{array}$ \\
\hline 5. & Abhyanga and Ooshma sweda & Sudha bala taila & For 1 day \\
\hline 6. & Utklesana & & 1 days \\
\hline 7. & Vamana & & Pravara vega 6 \\
\hline 8. & Samsarjana karma & Pippalyadi anuvasana taila & For 3 days 20 ml twice daily \\
\hline 9. & Vicharana sneha pana & before food \\
\hline 10. & Abhyanga and Ooshma sweda & Karpooradi taila & 3 days \\
\hline 11. & Virechana & Kandharva eranda & For 7 days \\
\hline 12. & Choorna pinda sweda & $\begin{array}{l}\text { Sneha vasti with Pippalyadi } \\
\text { anuvasana taila } \\
\text { Kashia vasti }\end{array}$ & D1, D2, D4, D6, D8 \\
\hline 13. & Mustadi raja yapana vasti & D3, D5, D7 \\
\hline 14. & Uttara vasti & Maha kalyanaka ghrita & For 5 days \\
\hline
\end{tabular}

\section{Discharge Medicine}

1. Sukumara ghrita $10 \mathrm{gm}$, twice daily before food

2. Misi choornam 5gm with Grita

Patient conceived within 2 months but spontaneous abortion occurred in $7^{\text {th }}$ week. Ama garbha srava followed by emotional imbalance of patient cause Sareerika and Manasika dosha dushti. Dosha samanwaya with Ama cause Srotho rodha and Avarana. The vitiated Doshas get lodged on Garbhasaya and Adhakaya. She developed severe pain and stiffness over legs, general weakness and indigestion. Second course of treatment begins with focus on Urusthambha and Sopha chikitsa. After Rookshana, Ama pachana and Agni deepana sodhana karma were done.

Internal medicines in second course of treatment

\begin{tabular}{|c|l|l|}
\hline S. No & \multicolumn{1}{|c|}{ Medicines } & \multicolumn{1}{c|}{ Dose } \\
\hline 1. & Vaiswanara choorna & 5gm. twice daily before food \\
\hline 2. & Gudoochi and Punarnava toyam & frequently \\
\hline 3. & Amrithotharam kashaya & 90ml twice daily before food \\
\hline 4. & Varanadi kashaya & $90 \mathrm{ml}$ twice daily before food \\
\hline 5. & Gokshura punarnavadi gulika & 1 tab with Kashaya \\
\hline 6. & Gudardraka & $5 \mathrm{gm}$ twice daily after food \\
\hline 7. & Sapthasaram kashaya & $90 \mathrm{ml}$ twice daily before food \\
\hline 8. & Sukumara grita & 1 tsp bed time \\
\hline 9. & Abhayarishta & $20 \mathrm{ml}$ twice daily after food \\
\hline
\end{tabular}


Shahina Mole S, Deepa C R. Ayurvedic Management of Recurrent Pregnancy Loss Due to Diminished Ovarian Reserve

\section{Procedures in $2^{\text {nd }}$ course of treatment}

\begin{tabular}{|c|l|l|l|}
\hline S. No & \multicolumn{1}{|c|}{ Procedure } & \multicolumn{1}{|c|}{ Medicine } & \multicolumn{1}{c|}{ Duration } \\
\hline 1. & Choorna pinda sweda & Kolakulathadi choornam & For 7 days \\
\hline 2. & Virechana & 20ml Gandharva eranda & Total 5 Vegas \\
\hline 3. & Snehapana & Kalyanaka grita & $\begin{array}{l}\text { For 7 days }(30 \mathrm{ml}, 60 \mathrm{ml}, 90 \mathrm{ml}, \\
120 \mathrm{ml}, 150 \mathrm{ml}, 160 \mathrm{ml}, 175 \mathrm{ml})\end{array}$ \\
\hline 4. & $\begin{array}{l}\text { Abhyanga and } \\
\text { Ooshma sweda }\end{array}$ & Satahwadi taila & For 3 days \\
\hline 5. & Virechana & Gandharva eranda & Total 4 Vegas \\
\hline 6. & Yoga vasti & $\begin{array}{l}\text { Sneha vasti - Maha Masha taila }(120 \mathrm{ml}) \\
\text { Kashiavasti-Gandharva hastadi kashaya }\end{array}$ & $\begin{array}{l}\text { D1, D2, D4, D6, D8 } \\
\text { D3, D5, D7 }\end{array}$ \\
\hline 7. & Uttara vasti & Maha kalyanaka grita & For 5 days \\
\hline
\end{tabular}

\section{Discharge Medicines}

1. Sukumara grita $10 \mathrm{gm}$, twice daily before food

2. Pippali choornam 3gm with Grita

Follow up treatment

Patient was admitted and given two courses of Mustadi raja yapana vasti.

\section{RESULTS}

Follow up and outcome: She got conceived after 4 months of treatment. Antenatal period was uneventful and she was administered with Masanumasika ksheera kashyayas. She delivered a female baby through LSCS on $26 / 12 / 2020$. Birth weight was $4.1 \mathrm{~kg}$ and baby cried immediate after birth.

\section{DISCUSSION}

Ayurveda gives elaborative description of female infertility by the name of Vandhyata. It is mentioned as an independent disease and as an Upadrava of many Yoni rogas. As per Ayurveda, vitiation of Artavavaha srotas is the principle cause of Vandhyata ${ }^{6]}$. Acharya Chakrapani clearly mentioned that Sukra (semen) is not received by a diseased Yoni and thus fertilization is hampered. Even if fertilization takes place implantation is hampered, hence viable pregnancy does not take place ${ }^{[7]}$. Acharya Charaka has mentioned Vandhyata as the result of Pradushta garbhasaya bija bhaga of sonita ${ }^{[8]}$. Acharya Susruta has mentioned Vandhya as Nashtartava ${ }^{[9]}$. Acharya Hareeta considered Recurrent Pregnancy Loss (RPL) as Garbhasravi vandhya[10]. Acharya Susruta, Charaka and Vagbhata included the condition among Vimsathi yoni rogas (20 gynecological disorders). Acharyas Susruta and Charaka mentioned the condition as Putragni[11,12] and Acharya Vagbhata mentioned as Jathagni[13]. Vamini yoni vyapat mentioned by Acharya Vagbhata can be taken as implantation failure and patient report with infertility[14]. Asrija/Apraja yoni vyapat is mentioned by Acharya Charaka where excessive bleeding per vagina occur even after conception[15]. Durdhara jathaharini[16] and Vasya jathaharini[17] mentioned by Acharya Kasyapa can be taken as first trimester and second trimester abortions. These are few context in our classics mentioned about infertility and recurrent pregnancy loss.

According to Ayurveda basic etiology of all disease is Mandagni[18]. Here Agni is affected due to irregular diet habit, lack of exercise, imbalanced use of Shad rasas etc. Due to Agni dushti Ahara rasa undergo improper Dhatu parinama and formation of Ama will occur. Ama anwaya (combined) with Tridoshas lead to Sama doshas and normal physiology got distorted. These lead to improper formation Artava/sukra dhathu. Amatwa and Agni mandya will in turn cause Kapha dosha kopa and channels of the body get blocked. These vitiated Doshas got Sthana samsraya in Garbhasaya and Artavavaha srotas and cause repeated pregnancy loss. It can be taken as imbalance of Hypothalamo pituitary ovarian axis and entire reproductive physiology got distorted. Here Kshetra dushti is due to chronic endometritis followed by recurrent pregnancy loss. The inflammatory condition of endometrium will alter the endometrium and it became hostile for implantation. Even implantation takes place chance of spontaneous abortion is high due to improper placental blood formation. Here the factors contributing Vandhyata include Bija roopa artava dushti, Dhatu roopa artava dushti and Garbhasaya dushti. Treatment focused on Amapachana, Agni deepana, Vata anulomana, Kapha samana and Mano anulomana. Management includes Sodhana karma, Stanika karma, Samana karma and psychological support. Sodhana regulate and restore the normal physiological function of body and reproductive system. Stanika chikitsa restore healthy state of Yoni, restore structural integrity and functional capacity of Kshetra. Only in healthy Yoni, conception 
occur as a result of union of healthy gametes along with descent of Jiva[19].

Udwarthana with Kolakulathadi choornam helps in Kapha samana and Agni deepanam[20]. Sneha pana with Pippalyadi anuvasana taila is done as it is best for Moodha vata anulomana and Taila itself has the property of Yoni marga visodhana[21]. Vamana alleviate Kapha dosha through Urdhwa marga. Virechana improves the quality of Bija (bija karmukata) [22]. Eranda moola is the best drug of choice for Vrishya and Vata hara[23]. So Gandharva eranda taila is used for Virechana. During first course treatment Sneha vasti was done with Maha masha taila. It is indicated in Sukra dhatu kshay ${ }^{[24]}$ and considering the principle Nareem tailena mashaischa pittalai samupaacharet[25]. So it is administered prior to Mustadi raja yapana vasti. Mustadi raja yapana vasti is indicated for Apaprajata nari and it has the property of both Kashaya vasti and Sneha vasti [26]. Kalyanaka grita is Sreshta for Pumsavana (improves the quality of ovum), Balya and Pushtya (nourishing). It also helps to keep the psychological stability of the patient [27]. As Suomanasya is the prime important factor for Garbha dharana [28], Kalyanaka grita is an ideal choice in this condition. Second course of treatment, considering the Ama avasta of patient Vaiswanara choornam, Amrithotharam kashaya etc., are selected for Rookshana, Ama pachana, and Agni deepana. After Ama nirharana and Agni deepana sodhana karma were done. Sukumara grita and Pippali choorna were given as discharge medicines as Sukumara grita is Balya, Rasayana, Vrishya, Deepana, Malanulomana and Garbhasaya sudhikara[29]. Pippali choornam is Padhya in Yoni roga and it has Rasayana property [30].

\section{CONCLUSION}

The divine quality of women is her reproductive capacity. Now a day's infertility is a grave issue among couple. It has a negative impact not only on their reproductive health but also on their family social and psychological wellbeing. Ayurvedic management of infertility is found to be very effective in diminished ovarian reserve, recurrent pregnancy loss, PCOD and associated complications. Ayurveda provide a non-invasive, low cost therapeutic protocol and they tend to improve the systemic health and wellbeing of the individual. It is the responsibility of Ayurveda community to make aware of couple to choose Ayurveda not only as a first therapeutic choice of infertility but also for preconception care.

\section{ACKNOWLEDGEMENT}

Humbly bow before the almighty for successful completion of the work. I would like to express my extreme gratitude towards Dr. Shahina mole. S, MD (Ay.) PhD, Professor, Department of Prasoothi Tantra and Stree roga, Govt. Ayurveda College,
Thiruvananthapuram for her valuable guidance and support.

\section{REFERENCES}

1. Dutta D C, DC Dutta's Textbook of Gynaecology, 8th ed. Kolkata: Jaypee Brothers Medical Publishers (P) Ltd; 2020 page no 188.

2. Lakshmi seshadri, essential of gynecology. 2nd edition, published by Wolters Kluwer Pvt. Ltd, page no 306.

3. Prof. Gyanendra Pandey, Harita Samhita. Vol-2, Chaukhamba Sanskrit series, Varanasi, page no 1312.

4. Prof. Srikantha Murthy K R, Susruta samhita vol-1, ed. 2004, Chaukhamba Orientalia, Varanasi, Sareera stana 2/33, page no 26.

5. Poor ovarian reserve, Padma Rekha jirge, journal of human reproductive science, J Hum Reprod Sci. 2016 Apr-Jun; 9(2): 63-69.

6. Prof. Srikantha Murthy K R, Susruta samhita Vol-1, reprint ed. 2017, Chaukhamba Orientalia, Varanasi, Sareera stana 9/12, page no 149.

7. Dr. Ram Karan Sharma, Charaka Samhita, Vol-5, Chaukhamba Sanskrit series, Varanasi, Chikitsa Stana 30/125 Chakrapani, page no 162.

8. Dr. Ram Krishna Sharma, Charaka samhita Vol-2, Chaukhamba Sanskrit Series, reprint 2013, Sareera stana 4/30, page no 388

9. Prof. Srikantha Murthy K R, Susruta samhita, Vol-3, Chaukhamba Orientalia Varanasi, reprint edition 2017, Uttara stana 38/10, page no 171.

10. Prof. Gyanendra Pandey, Harita Samhita. Vol-2, Chaukhamba Sanskrit series, Varanasi, page no 1313.

11. Prof. Srikantha Murthy K R, Susruta samhita, Vol3, Chaukhamba Orientalia Varanasi, reprint edition 2017, Uttara stana 38/10, page no 171.

12. Dr. Ram Krishna Sharma, Charaka samhita Vol-5, Chaukhamba Sanskrit Series, Varanasi, reprint 2013, Chikitsa Stana 30/28, page no 136.

13. Prof. Srikantha Murthy K R, Ashtanga Hridayam, Vol-3, 6th ed. 2012, Chaukhamba Krishnadas Academy, Varanasi, Uttara Stana 33/34, page no 311.

14. Prof. Srikantha Murthy K R, Ashtanga Hridayam, Vol-3, 6th ed. 2012, Chaukhamba Krishnadas Academy, Varanasi, Uttara Stana 33/38, page no 312.

15. Dr. Ram Krishna Sharma, Charaka samhita Vol-5, Chaukhamba Sanskrit Series, Varanasi, reprint 2013, Chikitsa Stana 30/16, page no 133.

16. Prof P V Tewari, Kasyapa Samhita, Chaukhamba Viswabharati Academy, Reprint 2016, Kalpa stana 6/37, page no 358 . 
17. Prof P V Tewari, Kasyapa Samhita, Chaukhamba Viswabharati Academy, Reprint 2016, Kalpa stana 6/37, page no 360.

18. Prof. Sreekantha Murthy K R, Ashtanga hridayam, Vol-2, ed 2018, Chaukhamba Krishnadas Academy, Varanasi, Nidana Stana 12/1, Page no113.

19. P V Sharma, Charaka Samhita, Vol-1, Chaukhamba Orientalia Varanasi, Sareera Stana $4 / 5$, page no 428.

20. Prof. Srikantha Murthy K R, Ashtanga Hridayam, Vol-1, 6th ed. 2009, Chaukhamba Krishnadas Academy, Varanasi, Sutra Stana 2/15, page no 25.

21. Prof. Srikantha Murthy K R, Ashtanga Hridayam, Vol-2, ed. 2018, Chaukhamba Krishnadas Academy, Varanasi, Chikita Stana 8/90, page no 320.

22. P V Tewari, Kasyapa Samhita, Chaukhamba Viswabharati publication, Reprint ed. 2016, Sidhi Stanam 2/7, page no 266.

23. P V Sharma, Charaka Samhita, Vol-1, Chaukhamba Orientalia Varanasi, Sutra stana 25, page no 168.
24. Dr.G.Prabhakara Rao, Sahasra yogam, Chaukhamba Publications, New Delhi, 1st ed. 2016, page no 541.

25. Prof. Srikantha Murthy K R, Ashtanga Hridayam, Vol-1, 6th ed. 2009, Chaukhamba Krishnadas Academy, Varanasi, Sareera Stana $1 / 20$, page no 363.

26. Dr. Ram Krishna Sharma, Charaka samhita Vol-6, Chaukhamba Sanskrit Series, reprint 2013, Sidhi stana $12 / 20$, page no 429.

27. Prof. Srikantha Murthy K R, Ashtanga Hridayam, Vol-3, 3th ed. 2000, Chaukhamba Krishnadas Academy, Varanasi, Uttara Stana 6/31, page no 61.

28. P V Sharma, Charaka Samhita, Vol-1, Chaukhamba Orientalia Varanasi, Sutra stana 25, page no 168.

29. Prof. Srikantha Murthy K R, Ashtanga Hridayam, Vol-2, ed. 2018, Chaukhamba Krishnadas Academy, Varanasi, Chikita Stana 13/46, page no 398.

30. Prof. Srikantha Murthy K R, Ashtanga Hridayam, Vol-3, 3th ed. 2000, Chaukhamba Krishnadas Academy, Varanasi, Uttara Stana 34/55, page no 325.

\section{Cite this article as:}

Shahina Mole S, Deepa C R. Ayurvedic Management of Recurrent Pregnancy Loss Due to Diminished Ovarian Reserve- A Case Report. International Journal of Ayurveda and Pharma Research. 2021;9(12):28-33.

https://doi.org/10.47070/ijapr.v9i12.2213

Source of support: Nil, Conflict of interest: None Declared
*Address for correspondence Dr. Deepa C R

PG Scholar,

Dept. of Prasoothi Tantra and Stree roga,

Govt. Ayurveda College,

Thiruvananthapuram, Kerala, India.

Email: drdeepacr.bams@gmail.com

Phone: 9495954439

Disclaimer: IJAPR is solely owned by Mahadev Publications - dedicated to publish quality research, while every effort has been taken to verify the accuracy of the content published in our Journal. IJAPR cannot accept any responsibility or liability for the articles content which are published. The views expressed in articles by our contributing authors are not necessarily those of IJAPR editor or editorial board members. 